\title{
New metal catalysts active for thermal polymerization of vegetable oils
}

\author{
Vinicius M. Mello ${ }^{\mathrm{a}, \mathrm{b}}$, Gustavo V. Oliveira ${ }^{\mathrm{a}, \mathrm{b}}$, José M.G. Mandarino ${ }^{\mathrm{c}}$, Mercedes C. Carrão-Panizzi ${ }^{\mathrm{d}}$, \\ Paulo A.Z. Suarez ${ }^{a, b, *}$ \\ a Laboratório de Materiais e Combustíveis, Universidade de Brasília, CP 4478, Brasília, DF, 70910-970, Brazil \\ ${ }^{\mathrm{b}}$ INCT-Catálise, Brazil \\ ' Embrapa Soja, Londrina, PR, Brazil \\ d Embrapa Trigo, Passo Fundo, RS, Brazil
}

\section{A R T I C L E I N F O}

\section{Article history:}

Received 17 April 2012

Received in revised form 3 July 2012

Accepted 8 July 2012

\section{Keywords:}

Thermal polymerization

Vegetable oils

Soybean oil

Nickel

Iron

Printing ink

\begin{abstract}
A B S T R A C T
The catalytic activity of several low-toxic metal compounds was tested in the polymerization of soybean oil to produce biobased resins suitable to be used as binder in printing inks (offset). Soybean was polymerized in the absence and presence of different complexes of the type $\mathrm{M}$ (Carboxylate) $)_{2}(\mathrm{M}=\mathrm{Ni}, \mathrm{Fe}$, $\mathrm{Co}, \mathrm{Cu}$ and $\mathrm{Sn}$ ) and all compounds showed activity. The best result was obtained using $\mathrm{Ni}(\mathrm{II})$, when was observed an apparent kinematic constant up to 2.4 times higher than when in the absence of any metal compound. It was also observed that the catalytic activity of the $\mathrm{Ni}(\mathrm{II})$ strongly depends upon the metal content and the reaction temperature. Testing different vegetable oils was observed that the catalytic activity was dependent on the number of double-bonds of the oil.
\end{abstract}

(c) 2012 Published by Elsevier B.V.

\section{Introduction}

In the formulation of inks, paints and coatings there are different components, such as binders, pigments, solvents and additives. The binder forms a recovering thin film in the surface where the ink, paint or coating is applied and its first role is to keep the pigments agglutinated and glued to the surface. However, depending on the coating or paint, the film may also protect the surface from corrosion, temperature or moisture, as well as any other specific desired properties (Mello and Suarez, 2012). Along the history different materials have been used as binder, being the most important natural polymers such as proteins and polymerized lipids. Nevertheless, in the last century different petrochemical based resins with tuned physical-chemical properties have dominated the binder market in all fields of coatings, paints and inks. Recently, as in many other fields (Doll and Erhan, 2006; Sharma and Kundu, 2006; Suarez et al., 2007; Sharma et al., 2007), environmental concerns and increasing demand for petroleum had leaded researchers to develop new technologies to produce binders using renewable raw materials (Erhan and Bagby, 1991).

\footnotetext{
* Corresponding author at: Laboratório de Materiais e Combustíveis, Universidade de Brasília, CP 4478, Brasília, DF, 70910-970, Brazil.

E-mail address: psuarez@unb.br (P.A.Z. Suarez).
}

One example is the use vegetable oils and their polymers as binder for printing inks (offset), especially to print newspapers and magazines. The former works published in the literature appeared in the 1970s and 1980s and were related to the use of gilsonite oil and tall oil blends (Kobayashi and Nozaki, 1978; Koritala et al., 1987; Kuzuwata, 1988; Moynihan, 1985). Unfortunately, these works resulted in unsuitable binders from both technical and economical points of view. Indeed, the limitations of this approach were associated to its high cost and also to availability of the raw materials, as well as printing equipment clean-up difficulties because of the use of gilsonite.

In sequence, by using soybean oil blended with thermally polymerized soybean oil was possible to produce black and colored printing inks with equal or better physical-chemical properties than when using petrochemical resins as vehicle. Indeed, when compared with petrochemical based ones, the biobased printing inks showed better friction resistance coefficient, improved degradability, higher compatibility with carbon Black pigment and light vehicle color that allowed the use of less pigment amount (Erhan and Bagby, 1993, 1994, 1995). The high performance of the soybean based ink, called Soyink ${ }^{\circledR}$, became competitive from an economical point of view in the last decade and several important newspaper and magazines in US are currently printed using this technology. However, its price is still high and the improving the process in order to reduce costs is still a great challenge to researchers. 
In this sense, it is well known that the main cost of vegetable oil based inks is associated with the thermal polymerization. Indeed, the thermal processing of the oils occurs in temperatures above $280^{\circ} \mathrm{C}$ and takes long reaction times. The only approach published in the literature to reduce the reaction time during thermal polymerization of vegetable oils was the use of organic catalysts, such as quinones (Archer, 1938). However, Erhan and co-worker have published an elegant paper showing these catalysts have low activity, being necessary to use high amount of quinones. For instance, the use of 5 mass\% of antraquinone could reduce only from 10 to $20 \%$ of the reaction time (Erhan and Bagby, 1991). Besides, a further step to take out this catalyst from the polymer was needed because of its low solubility in the ink leaded to undesired properties, which would obviously increase production costs (Erhan and Bagby, 1992, 1994).

As far as our knowledge, there are no processes in the literature describing efficient catalysts that could diminish the reaction time when used in low catalytic amounts. Thus, the aim of this work was to study the catalytic activity of different low-toxic metal compounds in the thermal polymerization of vegetable oils and the main goal was to found a catalyst able to significantly reduce the reaction time even when used in small amounts.

\section{Materials and methods}

\subsection{Materials}

Reagents $\mathrm{FeCl}_{2} \cdot 4 \mathrm{H}_{2} \mathrm{O}, \mathrm{CoCl}_{2} \cdot 6 \mathrm{H}_{2} \mathrm{O}, \mathrm{SnCl}_{2} \cdot 6 \mathrm{H}_{2} \mathrm{O}, \mathrm{NiCl}_{2} \cdot 6 \mathrm{H}_{2} \mathrm{O}$, $\mathrm{CuCl}_{2} \cdot 2 \mathrm{H}_{2} \mathrm{O}, \mathrm{HCl}, \mathrm{NaOH}, \mathrm{Na}_{2} \mathrm{SO}_{4}$ and hexane were purchased from Vetec Química Fina Ltda. Alkali-refined soybean, canola, corn and sunflower oils were obtained from Bunge Alimentos. Palm oil was purchased from Master Food Ltda. All materials were used as received without any further purification.

\subsection{Instrumental}

The DRIFT FT-IR spectra (diffuse reflectance infrared Fourier transform) were obtained from powder samples on a Bruker Equinox 55 interferometer (Ettlingen, Germany). The FT-IR spectra were stored in the Kubelka-Munk mode and are the average of 32 scans at a nominal spectral resolution of $4 \mathrm{~cm}^{-1}$. The thermal analysis (TGA and DTA) was performed on a DTG-60 Shimadzu instrument under $\mathrm{N}_{2}$ flow $\left(50 \mathrm{~mL} \mathrm{~min}^{-1}\right)$. The samples were analyzed in a platinum pan from 25 to $800^{\circ} \mathrm{C}$ with $10^{\circ} \mathrm{C} / \mathrm{min}$ heating rate.

\subsection{Preparation of metal complexes}

$\mathrm{Fe}(\mathrm{II}), \mathrm{Ni}(\mathrm{II}), \mathrm{Co}(\mathrm{II}), \mathrm{Cu}(\mathrm{II})$ and $\mathrm{Sn}(\mathrm{II})$ were complexed with Carboxylate ligants derived from palm oil fatty acids. In a Becker flask were added palm oil fatty acids $(0.02 \mathrm{~mol})$ and $\mathrm{NaOH}(0.025 \mathrm{~mol})$ and the mixture was kept under stirring for $3 \mathrm{~h}$. Then, one of the metal chlorides $(0.01 \mathrm{~mol})$ was added and left under stirring for $4 \mathrm{~h}$, maintaining $\mathrm{pH}$ in 8 . The obtained precipitated was dissolved in hexane and the solution was washed three times with distilled water. The solvent was then removed under reduced pressure in a rotaevaporator and the obtained metallic complex characterized using FT-IR, TGA. The metal content was gravimetrically determined by calcinating the complexes at $800^{\circ} \mathrm{C}$ for $24 \mathrm{~h}$.

\subsection{Vegetable oil thermal polymerization}

Alkali-refined vegetable oil $(500 \mathrm{~g})$ was polymerized in a $1.0 \mathrm{~L}$ five necked reaction flask equipped with a mechanic stirrer, reflux condenser, nitrogen atmosphere and heater, as shown in Fig. 1.

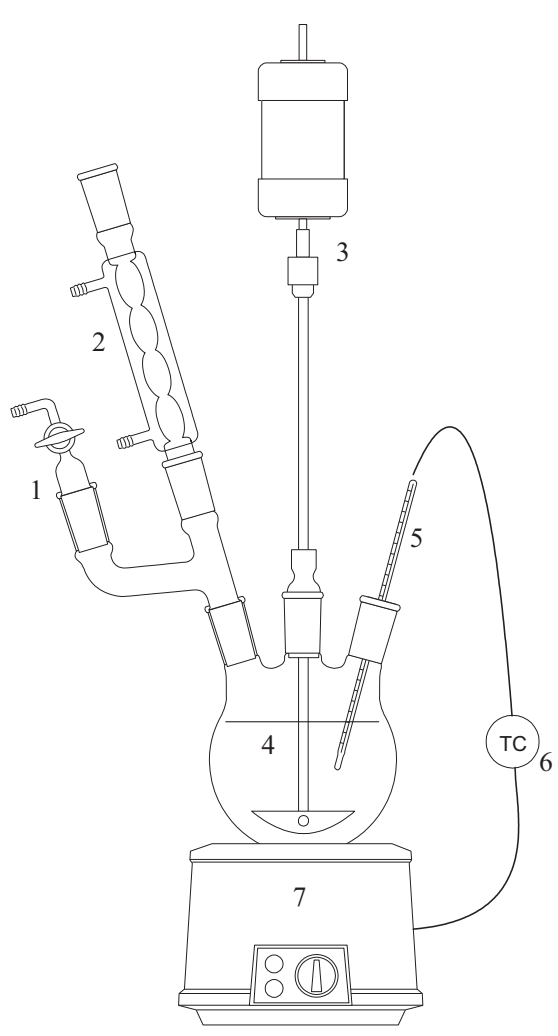

Fig. 1. Thermal polymerization system: (1) nitrogen flow; (2) reflux condenser; (3) mechanical stirrer; (4) reactor; (5) thermopar; (6) temperature control; and (7) heater.

Samples were taken in $0.0,1.0,1.5,2.0,2.5$ and $3.0 \mathrm{~h}$ and their kinematic viscosities were estimated using an ubbelohde viscosimeter according to ASTM D445. For each reaction, the apparent kinematic viscosity constants $(k)$ were determined plotting Ln (kinematic viscosity) versus time, according to the linear function $\ln \eta=\mathrm{k} . \mathrm{t}$.

\section{Results and discussion}

\subsection{Complexes synthesis and characterization}

Divalent metal ions complexes with the general formula $\mathrm{M}$ (Carboxylate $)_{2}$ were synthesized according to Fig. 2. The molecular formula was confirmed by gravimetric analysis after calcinating the complexes at $800^{\circ} \mathrm{C}$ for $24 \mathrm{~h}$ under oxygen atmosphere. Indeed, it was obtained 7, 8, 9, 12 and 19 mass\%, respectively, for the $\mathrm{Ni}$, Fe, $\mathrm{Co}, \mathrm{Cu}$ and $\mathrm{Sn}$ complexes.

The complexes were analyzed by FT-IR and in Fig. 3 is shown their spectra. As can be depicted from Fig. 3, the main important change in the spectra after the complexation is the absorption at $1708 \mathrm{~cm}^{-1}$ due to fatty acid carboxylic group, which diminished its intensity, and a new absorption at $1600 \mathrm{~cm}^{-1}$ that may be attributed to the complexed carboxylic group.

The TGA thermal analyses of the complexes are shown in Fig. 4. As can be depicted from this figure, the decomposition of all complexes start at $250^{\circ} \mathrm{C}$ and, different from the starting fatty acids

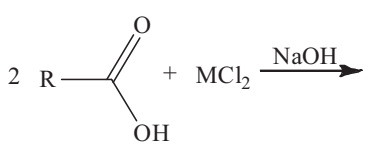<smiles>[R]C1=[Y10]2(O1)OC([R])O2</smiles>

Fig. 2. Preparation of metal complexes of the type $M(\text { Carboxylate })_{2}(\mathrm{M}=\mathrm{Ni}, \mathrm{Fe}, \mathrm{Co}$, $\mathrm{Cu}$ and $\mathrm{Sn}$; Carboxylate $=$ palm-tree oil fatty acids carboxylates $)$. 


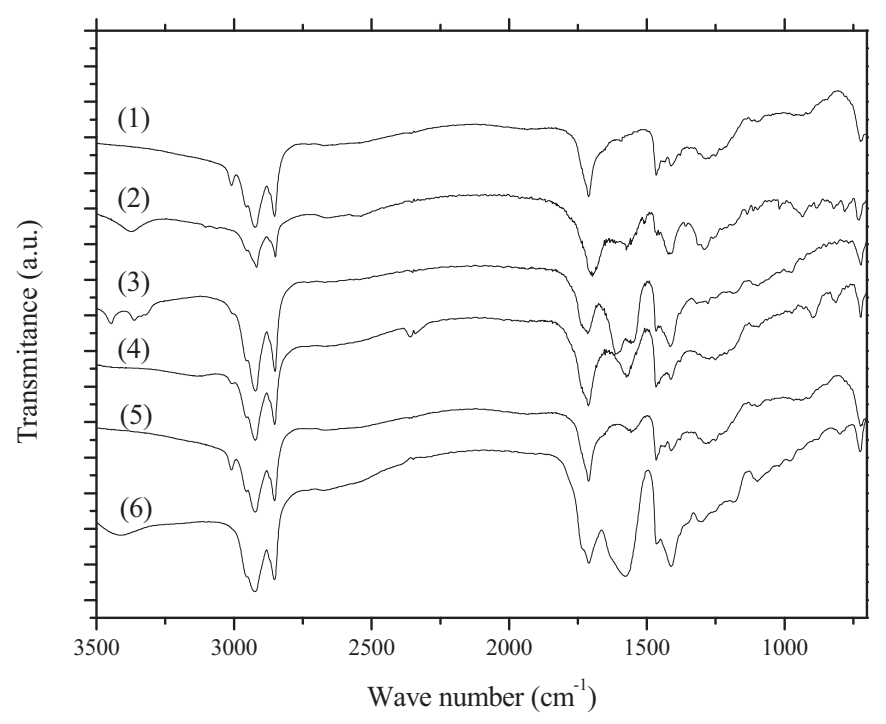

Fig. 3. FT-IR spectra of palm-tree oil fatty acids (1) and its complexes of the type $\mathrm{M}^{+2}$ (palm-tree oil carboxylates) $)_{2}$, where $\mathrm{M}=\mathrm{Co}(2), \mathrm{Cu}(3), \mathrm{Fe}(4), \mathrm{Sn}$ (5) and Ni (6).

mixture, behaves a complicated mechanism with different steps. These different steps are probably related to the decomposition of the alkyd chains of the carboxylate ligands. This result strongly indicates that the catalysts are partially decomposed in the reaction conditions. However, the main importance of using these complexes instead of the stable starting divalent ion salts is their high solubility in the vegetable oil, homogenizing the reaction media.

\subsection{Catalytic studies in polymerization}

There are some mechanistic studies published in the literature about thermal polymerization of vegetable oils (Archer, 1938; Sims, 1957). These studies suggest the thermal polymerization may have different step-reactions. One possible path is the isomerization of double bonds into trans conjugated systems, followed by cyclization via Diels-Alder reaction of the formed conjugated dienes with double bonds from other chains acting as dienenophile. This reaction leads to the formation of tetrasubstituted cyclohexenes which links different alkyl chains. Another possible pathway is the radicals

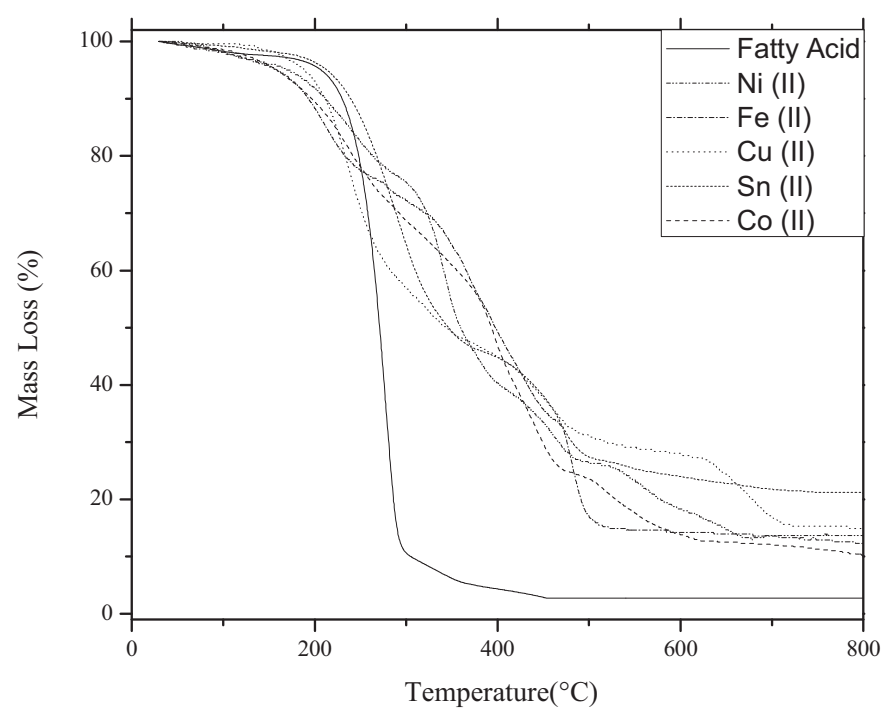

Fig. 4. Thermogravimetric analysis of the starting mixture of fatty acids and its complexes with Ni (II), Fe (II), Co (II), Cu (II) e Sn (II).
Table 1

Apparent kinematic viscosity constant and viscosity after $3 \mathrm{~h}$ of thermal polymerization of soybean oil at $300^{\circ} \mathrm{C}$.

\begin{tabular}{|c|c|c|c|c|}
\hline Entry & Catalysts & $k \cdot 10 \mathrm{~h}^{-1 \mathrm{a}}$ & $k_{\text {(Cat.) }} / k_{\text {(No Cat.) }}{ }^{\mathrm{b}}$ & $\begin{array}{l}\text { Viscosity after } \\
3 \mathrm{~h}(\mathrm{cSt})\end{array}$ \\
\hline 01 & No catalyst & 3.86 & 1.00 & 113 \\
\hline 02 & $\mathrm{Ni}(\mathrm{II})$ & 9.20 & 2.39 & 455 \\
\hline 03 & $\mathrm{Fe}(\mathrm{II})$ & 8.83 & 2.29 & 446 \\
\hline 04 & $\mathrm{Cu}$ (II) & 8.70 & 2.25 & 445 \\
\hline 05 & Sn (II) & 6.95 & 1.80 & 286 \\
\hline 06 & Co (II) & 6.35 & 1.65 & 234 \\
\hline
\end{tabular}

a $k$ is the apparent kinematic viscosity constant

b $k_{\text {(Cat) }} / k_{\text {(No Cat.) }}$ corresponds to the relationship between the constant obtained with $\left(k_{(\text {Cat. }}\right)$ and without $\left(k_{\text {(No Cat. })}\right)$ catalyst.

polymerization process. It is worth mentioning that these reactions may occur simultaneously and that it is rough to determine the importance of each one in the polymer formation. Thus, our first approach was study complexes of metal know in the literature as active for regular Diels-Alder reactions, such as $\mathrm{Ni}^{+2}, \mathrm{Fe}^{+2}$, $\mathrm{Cu}^{+2}, \mathrm{Sn}^{+2}$ and $\mathrm{Co}^{+2}$ (Wender and Smith, 1998; Ruff et al., 1995; Liu et al., 2011.). Note that cobalt and cupper complexes are also known in the literature as promoters of redox processes and radical polymerization (Mallegol et al., 2000; Kickelbick et al., 1999).

In sequence, soybean oil was thermally polymerized in the absence and presence of all prepared $\mathrm{M}$ (Carboxylate $)_{2}(\mathrm{M}=\mathrm{Ni}, \mathrm{Fe}$, $\mathrm{Co}, \mathrm{Cu}$ and $\mathrm{Sn}$ ) and in Fig. 5a are presented the viscosity of the reaction bulk during these polymerizations. Note that the viscosity is proportional to the polymerization degree. It means, as the oil chains are linked, either by radicals polymerization or Diels-Alder cyclization, and, thus, the molecular weight increases, the viscosity of the media gets higher. Plotting the natural logarithm of the kinematic viscosity versus time leaded to a linear plot and the apparent kinematic constant was obtained (Fig. 5b and values are listed in Table 1). As become clear from the results presented in Fig. 5 and Table 1, all tested complexes showed activity for the polymerization as far as the kinematic viscosity in similar times and temperature are always higher than when the reaction was carried out in the absence of metal ions (no catalyst added). Comparing the different catalysts we found out that $\mathrm{Ni}(\mathrm{II})$ presented the highest activity. Indeed, when comparing with the reaction carried out in the absence of catalyst, the polymerization assisted by $\mathrm{Ni}$ (II) showed after $3 \mathrm{~h}$ an apparent kinematic constant up to 2.4 times higher and the viscosity increased up to 4 times. Note that $\mathrm{Cu}(\mathrm{II})$ and $\mathrm{Fe}(\mathrm{II})$ exhibit comparable activity than $\mathrm{Ni}(\mathrm{II})$.

Because of its higher activity when compared with the other complexes $\mathrm{Ni}$ (II) was chosen for further studies. At first the metal amount was varied from zero to 0.2 mass\% and the kinematic viscosity apparent constant $(k)$ was determined (see results in Table 2 ). It becomes clear from Table 2 that $k$ increases with the metal complex concentration, strongly indicating a catalytic activity of the metal compound. It is important to highlight that even when using tinny amounts of the catalyst 0.0002 mass\% a high activity was observed, doubling $k$ when compared with the non-catalyzed reaction.

Table 2

Apparent kinematic viscosity constant $(k)$ of soybean oil polymerization at $300{ }^{\circ} \mathrm{C}$ varying the amount of $\mathrm{Ni}$ (II) carboxylate complex from zero to $0.2 \mathrm{mass} \%$.

\begin{tabular}{llll}
\hline Entry & $\mathrm{Ni}(\mathrm{II})$ variation $(\mathrm{w} / \mathrm{w})$ & $k \cdot 10 \mathrm{~h}^{-1}$ & Viscosity after $3 \mathrm{~h}$ \\
\hline 01 & 0 & 3.86 & 113 \\
07 & 0.0002 & 6.80 & 257 \\
08 & 0.001 & 7.32 & 312 \\
09 & 0.04 & 8.56 & 429 \\
02 & 0.1 & 9.20 & 455 \\
10 & 0.2 & 9.32 & 468 \\
\hline
\end{tabular}



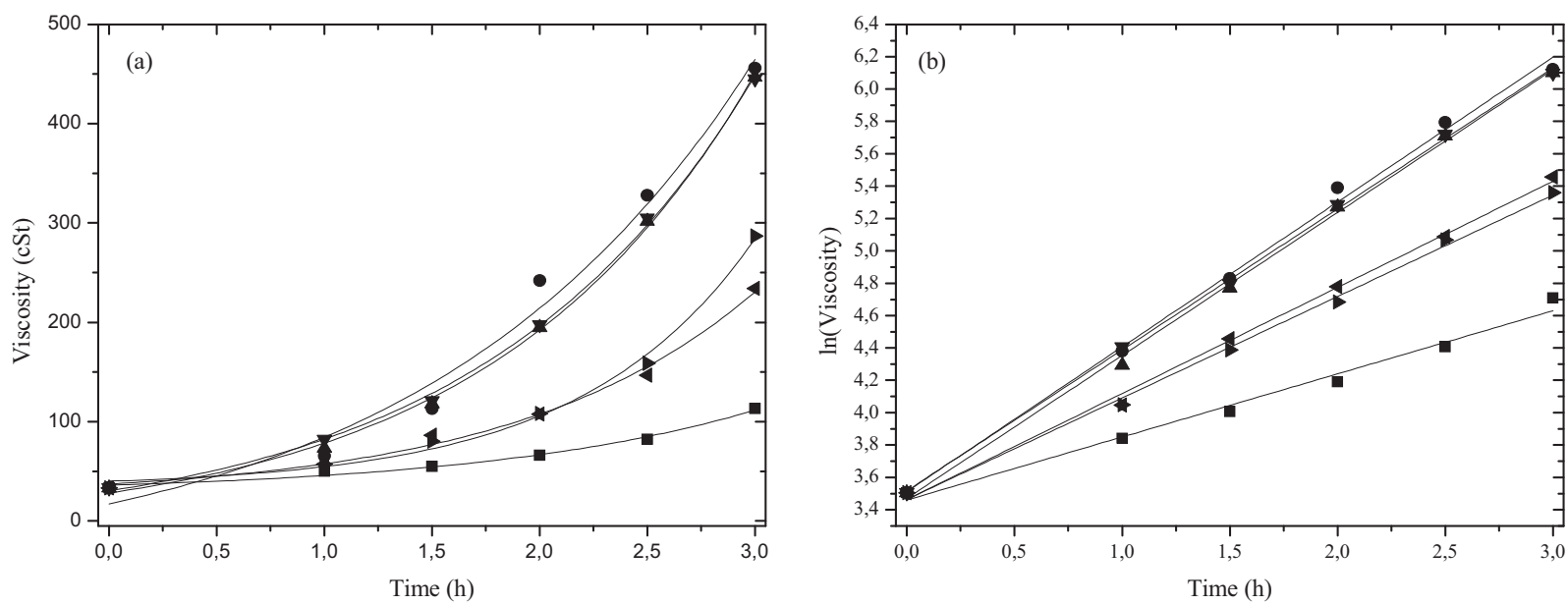

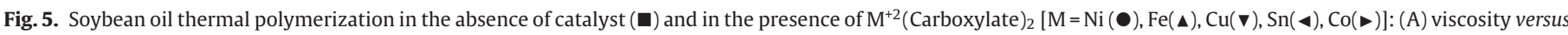
time and (B) Ln (viscosity) versus time.

Table 3

Apparent kinematic viscosity constant $(k)$ of soybean oil polymerization at 280,300 and $310^{\circ} \mathrm{C}$ in the presence of 0.1 mass $\%$ of $\mathrm{Ni}(\mathrm{II})$ carboxylate complex.

\begin{tabular}{lllcc}
\hline Entry & Temperature $\left(\mathrm{C}^{\circ}\right)$ & Catalyst & $k \cdot 10 \mathrm{~h}^{-1}$ & Viscosity after $3 \mathrm{~h}$ \\
\hline 11 & 280 & - & 1.97 & 63 \\
01 & 300 & - & 3.86 & 113 \\
12 & 310 & - & 8.55 & 560 \\
13 & 280 & $\mathrm{Ni}(\mathrm{II})$ & 3.58 & 98 \\
02 & 300 & $\mathrm{Ni}(\mathrm{II})$ & 9.20 & 455 \\
14 & 310 & $\mathrm{Ni}(\mathrm{II})$ & 13.8 & 2100 \\
\hline
\end{tabular}

In sequence, the $\mathrm{Ni}(\mathrm{II})$ amount was fixed in 0 and $0.1 \mathrm{mass} \%$ and the temperature was varied from 280 to $310^{\circ} \mathrm{C}$ and the $\mathrm{k}$ for the different reactions are listed in Table 3 . It was observed that the $k$ strongly increases in this temperature range, either for the noncatalyzed or the catalyzed reactions. It was also observed that for the same temperature $k$ is always higher when $\mathrm{Ni}(\mathrm{II})$ is used.

Finally, the Ni(II) complex catalytic activity was evaluated for other vegetable oils containing different unsaturation degrees (double-bonds content). Indeed, the unsaturation degree of the oils increases from canola $<$ corn $<$ sunflower $<$ soybean. It was tested the polymerization of the oils at $300^{\circ} \mathrm{C}$ in the presence of $\mathrm{Ni}$ (II) $(0.1 \mathrm{mass} \%)$ and the calculated $\mathrm{k}$ for the reactions are listed in Table 4 . It becomes clear from the results presented in Table 4 that as expected there is a direct relation between the unsaturation degree and $k$.

\section{Table 4}

Apparent kinematic viscosity constant $(k)$ of different oils polymerization at $300^{\circ} \mathrm{C}$ in the presence of 0.1 mass\% of $\mathrm{Ni}(\mathrm{II})$ carboxylate complex.

\begin{tabular}{lllll}
\hline Entry & Vegetable oil & Catalyst & $k \cdot 10 \mathrm{~h}^{-1}$ & Viscosity after $3 \mathrm{~h}$ \\
\hline 01 & Soybean & - & 3.86 & 113 \\
15 & Sunflower & - & 3.71 & 106 \\
16 & Corn & - & 3.43 & 100 \\
17 & Canola & - & 2.23 & 80 \\
02 & Soybean & $\mathrm{Ni}$ (II) & 9.20 & 455 \\
18 & Sunflower & $\mathrm{Ni}$ (II) & 9.01 & 434 \\
19 & Corn & $\mathrm{Ni}$ (II) & 8.60 & 381 \\
20 & Canola & $\mathrm{Ni}(\mathrm{II})$ & 5.96 & 239 \\
\hline
\end{tabular}

\section{Conclusions}

In summary, we found out that different metal complexes of the type $\mathrm{M}$ (Carboxylate $)_{2}$ are active for vegetable oils polymerization. The Ni(II) complex showed a high catalytic activity even when a tiny amount of the catalyst was added. Indeed, we could polymerize oils with a high energy saving, since the reaction occurs in high temperature $\left(300^{\circ} \mathrm{C}\right)$ and the presence of only 0.1 mass\% of $\mathrm{Ni}(\mathrm{II})$ reduced $60 \%$ of the time needed to achieve a kinematic viscosity of the resin of $113 \mathrm{cSt}$. This is an important result because it can improve the economical viability of producing printing inks using vegetable oils.

\section{Acknowledgements}

The authors are thankful to EMBRAPA, CAPES, FINEP, FAPDF, $\mathrm{CNPq}$ (Brazil) for financial support. The authors wish also to thank CNPq for their research fellowships.

\section{References}

Archer Daniels Midland Company, 1 US2213935, 1938.

Doll, K.M., Erhan, S.Z., 2006. Synthesis and performance of surfactants based on epoxidized methyl oleate and glycerol. J. Surfactants Deterg. 9 (4), 377-383.

Erhan, S.Z., Bagby, M.J., 1991. Lithographic and letterpress ink vehicles from vegetable oils. J. Am. Oil Chem. Soc. 68, 635-638.

Erhan, S.Z., Bagby, M.O., 1992. Gel permeation chromatography of vegetable-oilbased printing ink vehicle. J. Appl. Polym. Sci. 46 (10), 1859-1862.

Erhan, S.Z., Bagby, M.O., 1993. Taga Proceedings Chelsea: Technical Association of the Graphic Arts , pp. 314-326.

Erhan, S.Z., Bagby, M.O., 1994. Taga Proceedings, Chelsea: Technical Association of the Graphic Arts , p. 313.

Erhan, S.Z., Bagby, M.O., 1995. Vegetable-oil-based printing ink formulation and degradation. Ind. Crops Prod. 4 (3), 237-246.

Kickelbick, G., Paink, H.J., Matyjaszewski, k., 1999. Immobilization of the copper catalyst in atom transfer radical polymerization. Macromolecules 32, 2941-2947.

Kobayashi, S., Nozaki, K., 1978. Japanese Patent 17716.

Koritala, S., Hesseltine, C.W., Pryde, E.H., Mounts, T.L., 1987. Biochemical modification of fats by microorganisms: A preliminary survey. J. Am. Oil Chem. Soc. 64 (4), 509-513.

Kuzuwata, M., 1988. Jpn. Kokai Tokkyo Koho, J.P. 63,227287 (88,227287).

Liu, X., Lin, L., Fend, X., 2011. Chiral N,N'-dioxides: new ligands and organocatalysts for catalytic asymmetric reactions. Acc. Chem. Res. 44 (8), 574-587.

Mallegol, J., Lemaire, J., Gardette, J.L., 2000. Drier influence on the curing of linseed oil. Prog. Org. Coat. 39, 107-113.

Mello, V.M., Suarez, P.A.Z., 2012. As formulações de tintas expressivas através da história. Rev. Virtual Quim. 4 (1), 2-12.

Moynihan, J.T., 1985. American Newspaper Publishers Association, U.S. Patent $4,519,841$. 
Ruff, D.H., Fiedler, S., Hanack, M., 1995. Synthesis and characterization of new bisdienopliles for Diels-Alder-polymerization. Synth. Met. 69, 579.

Sharma, B.K., Perez, J.M., Erhan, S.Z., 2007. Soybean oil-based lubricants: a search for synergistic antioxidants. Energy Fuels 21, 2408-2414.

Sharma, V., Kundu, P.P., 2006. Addition polymers from natural oils - a review. Prog. Polym. Sci. 31, 983-1008.

Sims, R.P.A., 1957. Possible mechanisms in thermal polymerization of vegetable oils. II. Polymer formation. J. Am. Oil Chem. Soc. 34 (9), 466.
Suarez, P.A.Z., Meneghetti, S.M.P., Meneghetti, M.R., Wolf, C.R., 2007. Transformação de triglicerídeos em combustíveis, materiais poliméricos e insumos químicos: algumas aplicações da catálise na oleoquímica. Quím. Nova 30, 667-676.

Wender, P.A., Smith, T.E., 1998. Transition metal-catalyzed intramolecular [4+2] cycloadditions: mechanistic and synthetic investigations. Tetrahedron 54 (7) 1255-1275. 